\title{
Faculty Members and Female School Principals and Cooperating Teachers' Emphases on Teaching Ethics and their Inclusion in Courses in Preparation Programs
}

\author{
Mohammad Nayef Ayasreh $^{1}$, Shima' Mkhymr Yahyaa ${ }^{1}$, Mohareb Ali Al Smadi²," \\ ${ }^{1}$ Department of Science of Education, Irbed University College, Al Balqa Applied University, Jordan \\ ${ }^{2}$ Department of Science of Education, Ajloun University College, Al Balqa Applied University, Jordan
}

Received June 30, 2020; Revised August 28, 2020; Accepted September 11, 2020

\section{Cite This Paper in the following Citation Styles}

(a): [1] Mohammad Nayef Ayasreh, Shima' Mkhymr Yahyaa, Mohareb Ali Al Smadi, "Faculty Members and Female School Principals and Cooperating Teachers' Emphases on Teaching Ethics and their Inclusion in Courses in Preparation Programs," Universal Journal of Educational Research, Vol. 8, No. 11, pp. 5237-5245, 2020. DOI: 10.13189/ujer.2020.081124.

(b): Mohammad Nayef Ayasreh, Shima' Mkhymr Yahyaa, Mohareb Ali Al Smadi (2020). Faculty Members and Female School Principals and Cooperating Teachers' Emphases on Teaching Ethics and their Inclusion in Courses in Preparation Programs. Universal Journal of Educational Research, 8(11), 5237-5245. DOI: 10.13189/ujer.2020.081124.

Copyright $\bigcirc 2020$ by authors, all rights reserved. Authors agree that this article remains permanently open access under the terms of the Creative Commons Attribution License 4.0 International License

\begin{abstract}
The study aimed to examine the perspectives of early childhood education of female students' teachers in Irbid and Ajloun University Colleges concerning emphasis of faculty members and female school principals and cooperating teachers on teaching ethics. To achieve the study objectives, a questionnaire was developed consisting of (3) domains: Faculty members' emphasis on teaching ethics; inclusion of teaching ethics in university courses; and emphasis of female school principals and cooperating teachers on teaching ethics. The study sample consisted of (100) female pre- service teachers from the two colleges; (50) pre- service teachers from each college. The results of the study showed that the level of faculty members, female school principals and cooperating teachers' emphasis on teaching ethics was moderate, while the female students' teachers' estimation for the domain of inclusion of teaching ethics in university courses was low. There were statistically significant differences in the students' teachers' estimation on the domains of: Faculty members' emphasis on teaching ethics, and emphasis of female school principals and cooperating teachers on teaching ethics, due to university college, in favor of Irbid University College, while no statistically significant differences due to university college on the third domain. In light of the results, the study recommends to add a university course
\end{abstract}

for teaching ethics, and to add an evaluation form addressing female students' teachers' compliance with teaching ethics.

Keywords Teaching Ethics, Teaching, Pre- service

\section{Introduction}

The quality of educational systems marks the progress of nations seeking to create a creative individual able to confront the new challenges of modern life. For these educational systems to achieve, such a key objective, human resources should be fully capitalized while working on promoting their ability to research and learning (Al-Hadid, 2011; Hamadanah, 2013). Since the educational system is relatively an architecture work needing advance planning where several variables and principals are taken into consideration so as such an educational system can keep abreast with the present without abandoning its basic authenticity (Al-Ghamdi, 2007; Al-Zoubi, 2011).

Educational development and reform needs to consider teaching as a professional work requiring the integration of 
different effort from various stakeholders and to take schools as the heart and soul of educational systems, since they are the main drivers of any targeted educational progress. Jordan has realized such a fact; paying great attention to develop its educational system to reach an educational system able to compete in a global knowledge community. Therefore, the national charter for the teaching profession issued by the educational training and supervision department affiliated to the Jordanian ministry of education was developed and released in 2018. The charter can be described as a key pillar in the teaching profession and this charter is now used as a reference for deriving teachers' selection standards (Jordanian Ministry of Education, 2018).

Professionalizing teaching only succeed only if profession ethics are fully developed. The national charter for the teaching profession included eight domains; teaching ethics domain focusing on the ethics employed to upraise teachers' performance in four levels: Novice, Teacher, expert, and leader (Saadeh, 2016; Al-Hamshari, 2000). Novice teachers are required to comply with teaching ethics while a leader teacher is expected to play a role model in the compliance of teaching ethics and to work on assisting students for constructing their personal vision and message.

Ethics are rooted features in humans (Ibn Manzur, 2003). Ethics as a concept is derived from the Greek word (Ethos) which implies the person's characteristics resulting from his actions (Fogothey, 1976). They are indeed judgments employed to judge actions displayed by the individual. If a given action displayed is consistent with these judgments, it is described as right. If not, it is not acceptable.

Knowing that teaching profession is one of the noblest professions practiced by individuals, there must be standards and governing regulations that every teacher should comply to and work on showing them while practicing teaching in addition to the pedagogical knowledge and subject related information in both school and university alike (Al-Ajmi, 2016; Ghanem Bassam, \& Abu Shuairah, 2008), and these include fidelity, objectivity, accuracy and social responsibility. While universities are those educational institutions targeting to make significant changes in students cognitions, their skills and attitude and to provide ministry of education with teaching staff able to fulfill the requirements of teaching professions, university academic environment consisting of university polices, regulations and syllabus in addition to faculty members should all abide to innovation and progress to be informed with all what is new in the different domains.

Since faculty of educations in the different universities play a vital role in teachers preparation, the field training program seeks to prepare pre- service to enter the true school culture in the different institutions of the ministry of education; either by training students teachers in one of the public or private schools at the ministry of education after completing a specific credit hours presented in one university semester in most Jordanian universities while providing educational supervision by one of the faculty members in these universities.

Giving the fact that professional ethics is one of the elements formulated among learners while learning, these are relatively hard to change since they become innate in one's personality and his self-concept (Al-Salem 2017; Abu Al-Hajj \& Al-Hajjaj, 2018), students' teachers should follow these ethics in their field training program. But, before asking pre- service to comply to these ethics that have become a standard for teachers selection since 2018, and to develop their career course in an attempt to attract and retain highly qualified teachers for the teaching profession, there is a need to examine the effect of three important variables; and these are university faculty members, university courses, cooperating principals and teachers. These variables are very important in providing ministry of education with effective teachers able to develop the educational system and enhance students learning.

Faculty members are the trusties on society ethics and the teaching ethics nowadays as the educational systems are facing rabid developments and continuous and accelerating changes needing for more effective qualifications provided for teachers. Furthermore, university courses are of great importance in student developments, thus, topics and subjects provided to students should be carefully designed and the cognitive, psychological, technical and social educational bases should be a key driver in their development. The greatest challenge nowadays is the transformation from outcomes-centered education to learner centered teaching. For these reasons, the inclusion of teaching ethics is now a main ingredient for building pre- service teachers personality in university courses has become an urgent need imposing itself on the educational plans and syllabus provided in teachers' preparation programs.

Knowing that teaching profession does not take its ethics from any religion, philosophy or policy, but from the educational society authority always seeking to progress and development, female school principals and cooperating teachers have a great influence on students' teachers' compliance with teaching ethics. This can be achieved either by capitalizing the opportunities stressing the importance of such ethics in teaching profession among female students teachers; a key for making students teachers more related with the teaching profession, something that will be in the future a peace for the student teacher now and the teacher later for judging a set of issues and situations in her career.

\section{Previous Studies}

In Jordan, Al-Hadid (2011) investigated secondary school Islamic education teachers' compliance to 
professional ethics from their principals' perceptions. Using questionnaire, the researcher collected data from the sample of the study. Results of the study showed that secondary school Islamic education teachers' compliance to teaching ethics was moderate. No statistically significant differences were found due to gender, qualification or years of experience.

In the same vain, Helen (2011) examined the most common issues that may affect (14) Australian teachers' compliance to the teaching ethics and found that ethics should be an integral part of the teaching learning process.

Al-Tashtoush and Mazahreh (2012) studied the practice degree of (60) educational supervisors working in the Jordanian Ministry of Education of teaching ethics from their perceptions in light of several variables, and found that their practice degree was moderate. Additionally, statistically significant differences were found in the practice degree of teaching ethics in light of qualification, specialization and years of experience.

Another study by Armor, Makopoulo and Chambers (2012) sought to identify physics teachers' compliance and commitment to teaching $\backslash$ ethics from their perceptions using a questioner. The results of the study indicated that their commitment and compliance was moderate stressing at the same time that future research should examine other school subjects' compliance to teaching ethics.

In the same line, Al-Zoubi (2013) aimed to identify cooperating females teachers compliance to teaching ethics using a sample of (113) female pre- service selected from Al Albayt University, Jordan. The results of the study showed that the compliance level was high; that years of experience had a significant effect on teaching ethics compliance level while qualification had no significant effect.

Another study by Al-Amoush, Al-Sarhan and Bani Khalid (2013) sought to examine faculty members at $\mathrm{Al}$ Albayt University compliance level to teaching ethics from students' perceptions. As cluster sample totaling (271) Jordanian students from Al Albayt University were selected in the first semester of the academic year 2010-2011. An instrument divided into (3) domains was used for data collection. It was found that the means scores of Al Albayt University faculty members compliance teaching professions was high $(\mathrm{M}=3.87)$. There were statistically significant differences in students' perceptions of faculty members' compliance to teaching ethics on the total score due to university level, in favor of second year or more students.

Furthermore, Tuwayqat (2015) studied head of academic departments at Al-Balqa'a Applied University in Jordan compliance level of professional ethics and found that faculty of engineering had the highest scores comparing to other faculties in the level of head of academic departments compliance level of professional ethics.

In Saudi Arabia, Al-Ajmi (2016) investigated male and female teachers' compliance to teaching ethics. The results of the study found high compliance level to teaching profession ethics. Additionally, there were statistically significant differences in the compliance level in light of gender, qualification and years of experience.

Using a sample totaling (570) male and female students, Al-Salem (2017) examined faculty members at King Saud University compliance level to teaching ethics and found that their level of compliance was moderate.

Another study by Abu Al-Hajj and Al-Ajaj (2018) investigated male and female teachers' compliance level to teaching ethics at the university educational directorate in Jordan from students' perceptions and its relationship with students' academic achievement and found that compliance degree was moderate. There was a statistically significant effect for the compliance degree on students' academic achievement.

\section{Comments on Literature Review}

This study meets with the previous studies in its general framework as it was used to enrich the theoretical framework and in the study's development instrument.

Reviewing previous studies, it can be acknowledged that most studies showed high or moderate levels of teachers' compliance to the teaching ethics as one of the key billers in the teaching learning process. These studies assist teachers' compliance to teaching ethics from their own perceptions such as the studies of Al-Ajmi (2016), Helen (2011) and Armor, Makopoulo and chambers (2012). Other studies such as Al-Hadid (2011) assist teachers' compliance to teaching ethics from educational supervisors while Abu Al-Hajj and Al-Ajaj (2018) used a sample of students to assist teachers compliance to teaching ethics. Al-Amoush, Al-Sarhan and Bani Khalid (2013) and Al-Salem (2017) assist compliance to teaching ethics among other populations such as faculty members. Al-Zoubi (2013) studies compliance level to teaching ethics among female cooperating teachers. All of these studies used questionnaire as the main instrument for data collection. This study is consistent with previous studies in terms of objectives and instruments, while it is different by attempting to identify the role of faculty members and university courses in directing female students teachers to comply to teaching ethics while stressing at the same time the role of female school principals and cooperating teachers in this process since they play a vital role in making students teachers show high levels of compliance of teaching ethics.

\section{Study Problem and Questions}

Considering the fact that teacher preparation and qualifications at the professional and cognitive aspects has been a main focus of Jordanian educational system since teachers are a focal point for the educational system to 
achieve its strategic goals and insuring that educational system can help student in attaining higher levels of academic achievement while stressing at the same time on improving the quality of learning experiences presented to students, for these reasons, the national charter for the teaching profession was developed based on the prospective national vision of Jordan for 2020/2025 emphasizing that teachers compliance to teaching ethics is a key standard for assessing them. Additionally, when knowing that universities are those educational institutions graduating these teachers in light of ethical standards enabling them to be ready to face the challenges of the ever changing learning teaching process, this study is an attempt to clarify the role of some variables on female pre- service teachers compliance to teaching ethics during their field training which is the last phase of teachers university preparation programs before joining ministry of education. In sum, the problem of the study may be stated in the following questions:

- What is the level of faculty members' emphases on teaching ethics from early childhood education female pre- service at Irbid and Ajloun Universities Colleges point of view?

- What is the inclusion level of university courses for teaching ethics from Irbid and Ajloun University Colleges female students' teachers' point of view?

- What is the level of female principals and cooperating teachers' emphases on teaching ethics from early childhood education female pre- service teachers at Irbid and Ajloun Universities Colleges point of view?

- $\quad$ Are there differences at the significant level $(\alpha=0.05)$ in the level of faculty members' emphases on teaching ethics and in the inclusion level of these ethics in university courses among early childhood education female pre- service teachers due to university college (Irbid University College vs. Ajloun University College)?

\section{Significant of the Study}

The significance of this study stems from the following:

- Identifying some of the key factors that may affect female students' teachers' adaptation to teaching ethics.

- The results of the study may benefit educators at Al-Balqa'a Applied University in more focusing on the importance of teaching ethics practice by their inclusion in syllabi provided in faculty of education.

- This study may contribute in developing filed training programs at faculty of education.

- It is hopefully that the results may be adopted by those responsible of the national charter of the teaching profession issued by educational training and supervision department at Jordanian Ministry of Education in the teachers' educational development framework.
- This study may add to the theoretical framework related to the compliance level to teaching ethics among early childhood teachers.

\section{Procedural Definitions}

- Teaching Ethics: A charter defining the principles and values that each teacher must comply to fulfill his duties.

- Irbid and Ajloun University Colleges: Two colleges affiliated to Al-Balqa'a Applied University in Jordan.

- Female Early Childhood Students Teachers: Those female students' teachers enrolling at department of educational sciences majoring in early childhood education who trained at one of the schools affiliated to the ministry of education in Jordan as the student teacher practice teaching for one semester.

\section{Limitations of the Study}

- Time Limitations: The study was conducted in the first semester of the academic year 2018/2019.

- Spatial Limitation: The study was confined to early childhood female students' teachers at Irbid and Ajloun University Colleges enrolling in filed training program at one of the schools in Jordanian Ministry of Education.

\section{Methods}

This section provides an overview of the methodology and procedures adopted to achieve the objectives of the study. It includes a description of the population, sample, and instrument of the study in addition to providing the main statistical analysis procedures used to answer the questions of the study.

\subsection{Population of the study}

The population of the study included all female students' teachers at department of educational sciences, Irbid and Ajloun University Colleges, participating in the field training program for the first semester of the academic year 2018/2019. The total number of the population was (152) female students' teachers.

\subsection{Sample of the Study}

The sample of the study consisted of (100) female students' teachers in the academic year 2018/2019 selected randomly. Table (1) shows the distribution of the sample based on the university college the students. 
Table 1. The study sample distribution based on "university college" variable

\begin{tabular}{ccc}
\hline Category & Frequency & Percentage \\
\hline Irbid College & 50 & 50.0 \\
Ajloun College & 50 & 50.0 \\
\hline Total & 100 & 100.0 \\
\hline
\end{tabular}

\subsection{Instrument of the Study}

To achieve the objectives of the study, the researchers developed a questionnaire consisting in the preliminary format of (40) items distributing on (3) domains: Faculty members, courses, female school principals and cooperating teachers where students' teachers are trained.

\subsection{Validity of the Instrument}

To ensure the face validity of the instrument, a jury of expertise specialized in Arabic language, English language, measurement and evaluation and education were asked to give any remarks about the items of the instrument. After their remarks were taken into consideration, the instrument in the final format consisted of (24) items, distributing on the same domains.

\subsection{Reliability of the Study}

To verify the reliability of the study instrument, test-retest method was used by administrating the instrument for the first time and re-administrating the same instrument to a sample totaling (30) pre- service teachers from the same population and out of the original sample of the study. Then, Pearson Correlation was calculated between their scores on the scale.

Table 2. Test-Retest, Cronbach Alpha Internal Consistency Reliabilities for Individual Domains and Total Instrument

\begin{tabular}{ccc}
\hline Domain & $\begin{array}{c}\text { Test-Retest } \\
\text { Reliability }\end{array}$ & $\begin{array}{c}\text { Internal Consistency } \\
\text { Coefficient }\end{array}$ \\
\hline Faculty Members & 0.84 & 0.79 \\
Courses & 0.83 & 0.82 \\
$\begin{array}{c}\text { Female Principal and } \\
\text { teachers } \\
\text { Total }\end{array}$ & 0.91 & 0.77 \\
\hline
\end{tabular}

Also, Cronbach alpha Coefficient for internal consistency reliabilities was calculated. Table (2) shows test-retest and internal consistency reliabilities for the individual domains and the total instrument. As seen these values are appropriate to achieve the objectives of the study.

\subsection{Variables of the Study}

This study included the following independent and depended variables as follow:

- The independent variables, which was: University College: Irbid, Ajloun.

- Dependent Variable: Faculty members, courses, and female school principals and cooperating teachers' emphasis on teaching ethics.

\subsection{Scoring}

A (5) point Likert Scale was used to score the instrument as follows: (Strongly Agree $=5$, Agree $=4$, Neutral $=3$, Disagree $=2$, strongly Disagree $=1$ ). The following measure was used to show response level:

- 1.00-2.33 Low

- 2.34-3.67 Moderate

- 3.68-5.00 High

\section{Results of the Study}

\subsection{First Question: What is the level of faculty members' emphases on teaching ethics from early childhood education female pre- service teachers at Irbid and Ajloun Universities Colleges point of view?}

To answer this question, Means and Standard Deviations of faculty members' emphases on teaching ethics from early childhood education female students' teachers at Irbid and Ajloun University Colleges point of view were calculated as seen in the table 3 .

Table (3) shows that the means scores ranged between (1.00-4.55), item (1) stating "Faculty members focus on the need to comply with the teaching ethics" ranked first $(\mathrm{M}=$ 4.55), while item (3) stating "Faculty members focus on some teaching ethics" ranked last $(\mathrm{M}=1.00)$. Also, the total mean score of faculty members was (3.10), with moderate level. 
Table 3. Means and Standard Deviations of Faculty Members' Emphases on Teaching Ethics from Early Childhood Education Female Students' Teachers at Irbid and Ajloun University Colleges Point of View Presented in Descending Order According to the Means

\begin{tabular}{|c|c|c|c|c|}
\hline Rank & Items & Means & S.D & Level \\
\hline 1 & Faculty members focus on the need to comply with the teaching ethics. & 4.55 & 0.500 & High \\
\hline 2 & Faculty members are role models for teaching ethics. & 4.40 & 0.550 & High \\
\hline 3 & Faculty members instruct female students' teachers about the importance of their role in \\
community service. & 3.98 & 1.035 & High \\
\hline 4 & Faculty members emphasize the importance of being committed to the teaching ethics during \\
field training. & 3.94 & 0.547 & High \\
\hline 5 & Faculty members are keen to include teaching ethics in the teaching courses. & 3.60 & 1.414 & Moderate \\
\hline 6 & Faculty members are keen to instill teaching ethics in female students' teachers. & 3.46 & 0.558 & Moderate \\
\hline 7 & Faculty members include teaching ethics when assessing female students' teachers' field training. & 3.05 & 1.077 & Moderate \\
\hline 8 & Faculty members organize additional activities focusing on teaching ethics. & 2.33 & 0.871 & Low \\
\hline 9 & Faculty members reward the student teacher who shows commitment to the teaching ethics in \\
training. & 2.03 & 0.171 & High \\
\hline 10 & Faculty members pose questions addressing teaching ethics using various evaluation methods. & 1.49 & 0.502 & Low \\
\hline 11 & Faculty members focus on some teaching ethics. & 1.00 & 0.000 & Low \\
\hline & Total Faculty Members Domain & 3.10 & 0.174 & Moderate \\
\hline
\end{tabular}

Table 4. Means and Standard Deviations of the Inclusion Level of University Courses for Teaching Ethics from Irbid and Ajloun University Colleges Female Students' Teachers' Point of View Ranged Condescendingly based on the Means Presented in Descending Order According to the Means

\begin{tabular}{|c|c|c|c|c|}
\hline Rank & Items & Means & S.D & Level \\
\hline 1 & $\begin{array}{l}\text { Teaching courses content emphasizes the importance to comply with teaching } \\
\text { ethics. }\end{array}$ & 2.93 & 1.018 & Moderate \\
\hline 2 & There is integration in addressing teaching ethics across university courses. & 2.47 & 0.627 & Moderate \\
\hline 3 & The teaching courses content focuses on the importance of teaching ethics. & 2.22 & 1.177 & Low \\
\hline 4 & $\begin{array}{l}\text { Teaching courses content emphasizes the positive influence of teaching ethics } \\
\text { compliance on society. }\end{array}$ & 2.19 & 0.581 & Low \\
\hline 5 & $\begin{array}{l}\text { Teaching courses content emphasizes the relationship between teaching ethics } \\
\text { and child education. }\end{array}$ & 1.61 & 0.650 & Low \\
\hline 6 & Teaching courses content focuses on some teaching ethics. & 1.24 & 0.955 & Low \\
\hline \multirow[t]{2}{*}{7} & There are specific courses addressing teaching ethics. & 1.19 & 0.720 & Low \\
\hline & Total Teaching Courses Domain & 1.98 & 0.442 & Low \\
\hline
\end{tabular}

\subsection{Second Question: What is the inclusion level of university courses for teaching ethics from Irbid and Ajloun University Colleges female students' teachers' point of view?}

To answer this question, Means and Standard Deviations of the inclusion level of university courses for teaching ethics from Irbid and Ajloun University Colleges female students' teachers' point of view were calculated as seen in the table 4.

Table (4) shows that the means scores ranged between (1.98-2.93), item (16) stating "Teaching courses content emphasizes the importance to comply with teaching ethics" ranked first $(\mathrm{M}=2.93)$, while item (14) stating "There are specific courses addressing teaching ethics" ranked last (M $=1.19$ ). Also, the total mean score of teaching courses was (1.98) with low level.
9.3. Third Question: What is the level of female principals and cooperating teachers' emphases to teaching ethics from early childhood education female students' teachers at Irbid and Ajloun Universities Colleges point of view?

To answer this question, means and standard deviations of the level of female principals and cooperating teachers' emphases to teaching ethics from early childhood education female students' teachers at Irbid and Ajloun Universities Colleges point of view were calculated as seen in the table 5 .

Table (5) shows that the means scores ranged between (1.15-4.05), item (19) stating "Female principals and teachers abide to the teaching ethics" ranked first $(\mathrm{M}=$ 4.05), while item (21) stating "Female principals and teachers focus on some of teaching ethics" ranked last $(\mathrm{M}=$ 1.15). Also, the total mean score of principals and teachers was (2.74) with low level. 
Table 5. Means and Standard Deviations of the Items Related to the Level of Female Principals and Cooperating Teachers' Emphases to Teaching Ethics from Early Childhood Education Female Students' Teachers at Irbid and Ajloun Universities Colleges Point of View Ranged Condescendingly based on the Means

\begin{tabular}{|c|c|c|c|c|}
\hline Rank & Items & Means & S.D & Level \\
\hline 1 & Female principals and teachers abide to the teaching ethics. & 4.05 & 0.925 & High \\
\hline 2 & $\begin{array}{l}\text { Female principals and teachers emphasize the role of the teaching ethics on } \\
\text { future teacher success. }\end{array}$ & 4.01 & 0.414 & High \\
\hline 3 & $\begin{array}{l}\text { Female principals and teachers are keen that students' teachers acquire teaching } \\
\text { ethics in field training. }\end{array}$ & 3.52 & 0.627 & Moderate \\
\hline 4 & $\begin{array}{l}\text { Female principals and teachers encourage students' teachers who comply with } \\
\text { teaching ethics. }\end{array}$ & 2.51 & 0.659 & Moderate \\
\hline 5 & $\begin{array}{c}\text { Female principals and teachers follow up students' teachers' practice of teaching } \\
\text { ethics. }\end{array}$ & 1.18 & 0.716 & Low \\
\hline \multirow[t]{2}{*}{6} & Female principals and teachers focus on some of teaching ethics. & 1.15 & 0.702 & Low \\
\hline & Total Principals and teachers Domain & 2.74 & 0.245 & Low \\
\hline
\end{tabular}

Table 6. Means, Standard Deviations and T-Test of the Differences in the Level of Faculty Members' Emphases on Teaching Ethics and in the Inclusion Level of these Ethics in University Courses among Early Childhood Education Female Students' Teachers due to University College (Irbid University College vs. Ajloun University College)

\begin{tabular}{|c|c|c|c|c|c|c|c|}
\hline & college & No. & $\mathbf{M}$ & S.D & $\mathbf{t}$ & df & $\begin{array}{c}\text { Sig. } \\
\text { (2-tailed) }\end{array}$ \\
\hline \multirow{2}{*}{ Faculty Members } & Irbid & 50 & 2.97 & 0.127 & \multirow{2}{*}{-13.048} & \multirow{2}{*}{98} & \multirow{2}{*}{0.000} \\
\hline & Ajloun & 50 & 3.24 & 0.079 & & & \\
\hline \multirow{2}{*}{ Courses } & Irbid & 50 & 1.91 & 0.531 & \multirow{2}{*}{-1.530} & \multirow{2}{*}{98} & \multirow{2}{*}{0.129} \\
\hline & Ajloun & 50 & 2.05 & 0.322 & & & \\
\hline \multirow{2}{*}{$\begin{array}{l}\text { female school principals and } \\
\text { cooperating teachers }\end{array}$} & Irbid & 50 & 2.60 & 0.252 & \multirow{2}{*}{-6.693} & \multirow{2}{*}{98} & \multirow{2}{*}{0.000} \\
\hline & Ajloun & 50 & 2.87 & 0.141 & & & \\
\hline
\end{tabular}

9.4. Question Four: Are there differences at the significant level $(\alpha=0.05)$ in the level of faculty members' emphases on teaching ethics and in the inclusion level of these ethics in university courses among early childhood education female preservice teachers in light of university college (Irbid University College vs. Ajloun University College)?

To answer this question, means and standard deviations of the differences in the level of faculty members' emphases on teaching ethics and in the inclusion level of these ethics in university courses among early childhood education female students teachers due to university college (Irbid University College vs. Ajloun University College) were calculated, and to clarify the statistical differences between the means scores, T-test was calculated, as shown in table 6 .

Table (6) shows that there are statistically significant differences at $(\alpha=0.05)$ due to university college, in the level of faculty members', and female school principals and cooperating teachers emphases on teaching ethics among early childhood female students' teachers, in favor of Irbid University College, while no statistically significant differences were found at $(\alpha=0.05)$ due to university college in the inclusion level of teaching ethics in university courses.

\section{Discussion}

The study aimed to determine the levels of faculty members and female school principals and cooperating teachers' emphases to teaching ethics and their inclusion in courses in preparation programs among Irbid and Ajloun University Colleges female students' teachers.

The study showed that the emphasize level of faculty members and female school principals and cooperating teacher on teaching ethics was moderate, while the inclusion level of these ethics was low. The study also showed that there were statistically significant differences in the emphasize level of faculty members and female school principals and cooperating teachers in light of university college, in favor of Irbid University College. This result is consistent with the results reported in Al-Hadid (2011), Al-Tashtoush and Muzirah (2012), Al-Salam (2017) and Abu Al-Hajj and Al-Hajjaj (2018) studies. No statistically significant differences were found due to university college in the inclusion level of teaching ethics in university course.

This result may be explained by the fact that faculty members are educators of high academic ranks having educational experience and they are strongly related to the educational society at Jordanian Ministry of Education. Furthermore, they are role models embodying teaching ethics. Therefore, they pay special attention to the importance of female students' teachers' compliance with teaching ethics. Nonetheless, such emphasize needs coordinated efforts with ministry of education by holding seminars and courses addressing the importance of teaching ethics in the educational realm. Finally, there 
should be more emphasize in including different evaluation methods for these ethics; to focus on them in the evaluation of female students' teachers in field training that contains semester planning, class management, and class evaluation.

As for the result indicating that the inclusion level of university courses for teaching ethics was low, this result may be explained by the nature of these courses within the program syllabus that should aim to achieve a full integration between what the Jordanian Ministry of Education requires of complying with these ethics are considered one of the basic competence for modern education, there should be a special course addressing teaching ethics and to be included with other courses such as contemporary issues and practical drills and exercises in early childhood education.

Noting the high level of female school principals and cooperating teachers emphases on teaching ethics, this result may still from the high focus of ministry of education in Jordan on the importance of teaching ethics as one of the main key factors in the Jordanian educational system in addition to being a focal factor for designing the national professional standards of teachers.

\section{Recommendations}

In light of the results, the study recommends:

- Adding a fourth domain in the field training evaluation form addressing female students' teachers' compliance with teaching ethics.

- The need for The Ministry of Higher Education to concentrate on teaching ethics acquisition among students' teachers by organizing training courses and workshops.

- More focus by faculty members in teachers' preparation programs on the importance for students' teachers to acquire teaching ethics.

- Examining in service teachers' compliance with teaching ethics,

- Organizing meetings with educators from Jordanian Ministry of Education to discuss the importance of teaching ethics.

\section{REFERENCES}

[1] Al-Ajmi, N. (2016). The degree of commitment to professional ethics by intellectual education teachers from their perspectives. Journal of Arab Studies in Education and Psychology, (87), 445-447.

[2] Al-Amoush, F. Al-Sarhan, K. \& Bani Khalid, K. (2013). Al Al-Bayt University faculty members' commitment to teaching ethics from students' point of view. Dirasat: Educational Sciences, 40(1), 569-582.
[3] Al-Ghamdi, H. (2007). Ethics of public teaching profession, ( $1^{\text {st }}$ Ed). Riyadh: Al-Rushd Library.

[4] Al-Hadid, N. (2011). The commitment level of Islamic Education teachers at the secondary level to the profession ethics from their school principals perspectives in Jordan. Unpublished Master Thesis, Amman Arab University, Jordan.

[5] Al-Hamshari, O. (2000). Introduction to education. Amman: Dar Al-Safa for Publishing, Distribution and Printing.

[6] Al-Salem, W. (2017). The reality of commitment of faculty members at King Saud University to the ethics of teaching profession from the perspective of male and female students. The International Interdisciplinary Journal of Education, 6(1), 177-187.

[7] Al-Tashtoush, R. \& Mazahreh, R. (2012). The degree of educational counselors practicing of counseling profession ethics from their point of view in the light of some variables. IUG Journal of Educational and Psychological Sciences, 20(2), 581-62.

[8] Al-Zoubi, R. (2013). The degree of commitment of the female cooperating teachers to teaching profession's ethics from the perspectives of the female trainee students at $\mathrm{Al}$ al-Bayt University. Unpublished Master Thesis, Al Albayt University, Jordan.

[9] K., Makopoulo, K. \& Chambers, F. (2012). Progression in physical education teachers' career-long professional learning: Conceptual and practical concerns. European Physical Education Review, 18(1), 62-77.

[10] Fagothey, S. (1976). Right and Reason: Ethics in Theory and Practice. Saint Louis: The C.V. Mosby Company.

[11] Ghanem, B. \& Abu Shuairah, K. (2008). Practical effective education at first stage of primary education: Theoretical and practice, ( $\left.1^{\text {st }} \mathrm{Ed}\right)$. Amman: Dar Al-Mujtama Al-Arabi for Publishing and Distribution.

[12] Hamadnah, A. (2013). The degree of commitment to ethics of teaching by Arabic language teachers from the principals' point of view in Mafraq directorate of education. Jordan Journal of Educational Sciences, 10(1), 29-50.

[13] Helen, J. (2012). Raising the bar: Ethics education for quality teachers. Australian Journal of Teacher Education, 36(7), 76-93.

[14] Ibn Manzūū, J. (2003). Lisān al-`Arab. Cairo: Dār al-Hadīth Publishing and Distribution.

[15] Marshall, K. (2015). Should supervisors intervene during classroom visits?. Phi Delta Kappan, 97(2), 8-13.

[16] Merc, A. (2015). The potential of general classroom observation: Turkish EFL teachers' perceptions, sentiments, and readiness for sction. Journal of Education Training studies, 3(4), 193-205.

[17] Ministry of Education. (2018). The national chatter for teaching profession. Amman: Management of Educational Training Center.

[18] Nasir, I. (2002). Foundations of education. Amman: Dar Ammar for Publishing and Distribution.

[19] Resnik, D. (2011). The Ethics of Science. Johanneshov: 
TPB.

[20] Saadeh, J. \& Ibrahim, A. (2016). Contemporary school curriculum, ( $8^{\text {th }}$ Ed.). Amman: Dar al-Fikr for Publication and Distribution.

[21] Togara, W. (2013). Faculty Views on the Teaching of Ethics to Accounting Students: The Zimbabwean Perspective.
Asian Social Science, 9(2), 191-201.

[22] Tuwayqat, M. (2015). The degree of commitment of faculty members at Umm Al-Qura University to the ethics of the profession from the point of view of departments' heads and the graduate students. Unpublished Master Thesis. Umm Al-Qura University, Saudi Arabia. 